\title{
Cytologic analysis of body fluids with an emphasis on malignant effusions
}

\author{
Ayyagari Sudha', Padmaja Korti ${ }^{2, *}$, Shailaja Prabhala ${ }^{3}$, Ashok Kumar Deshpande ${ }^{4}$ \\ ${ }^{1,2}$ Assistant Professor, ${ }^{3,4}$ Professor, Dept. of Pathology, Kamineni Academy of Medical Sciences and Research \\ Centre, Rangareddy District, Hyderabad, India
}

*Corresponding Author:

Email: padmajakorti@yahoo.com

\begin{abstract}
Introduction: Fluid cytology, a relatively non invasive technique, throws light on both malignant and non malignant causes of effusions. It especially contributes in cancer research and staging of various tumors.

Materials and Methods: This was a retrospective study done over a period of two years from January 2014 to December 2015 in the department of Pathology, Kamineni Academy of Medical Sciences and Research Centre, Hyderabad. The body fluids included in the study were pleural, peritoneal, pericardial and synovial fluids. All other fluids were excluded. The relevant clinical data was noted. Gross, cell count and cytomorphological examinations of fluid were done.

Results: Out of 302 cases, pleural fluids, 148 (49.0\%) cases, were most common, followed by peritoneal fluid, $125(41.39 \%)$ cases and least common was pericardial fluid, 8 (2.64\%) cases. The maximum numbers of cases was in $5^{\text {th }}$ decade. The age range was 3 years to 84 years. Female preponderance was observed with M: F ratio of 1: 1.17. Lymphocyte rich exudates were most common in pleural effusion. In peritoneal and pericardial effusions, transudates were more and suppurative inflammation was predominant in synovial fluid analysis. Over all, malignant effusions constituted $18.54 \%$ of effusions. Metastatic adenocarcinoma was the commonest malignancy detected in all body cavity effusions.

Conclusions: Fluid cytology is relatively painless, simple, cost effective, rapid technique that yields quick and reliable results. Some cases may present major interpretative challenges to the pathologist. Ancillary studies such as cell count, biochemical, microbiologic evaluation, cell block and immunohistochemistry (IHC) study help in accurate identification of diagnosis.
\end{abstract}

Keywords: Body fluids, Malignant effusions, Transudates.

Received: 27th July, 2017

Accepted: $17^{\text {th }}$ October, 2017

\section{Introduction}

Effusion cytology is study of cells within the fluids of serous cavities, mainly the pleural, peritoneal and pericardial fluids. It is a useful means of studying the different pathologic processes and thereby elucidating the cause of effusion. ${ }^{1,2}$ The diagnostic yield of effusion fluid is higher than needle biopsy since the cell population present in the sediment is representative of a much larger surface area. ${ }^{3-5}$ On differentiating effusion into transudates and exudates one can identify the underlying pathological process there by guiding the further investigations. The most important and also challenging task of effusion cytology is detection of malignant cells which helps in staging of malignancy and also in monitoring of response to therapy. ${ }^{6}$ This study was carried out to know the trends of various types of effusions diagnosed in a tertiary care centre with an emphasis on malignant effusion.

\section{Materials and Methods}

The present study was carried out in the department of Pathology, Kamineni Academy of Medical Sciences and Research Centre, Hyderabad from January 2014 to December 2015. All the cases of neoplastic and non neoplastic diseases with effusion of pleural, peritoneal, pericardial and synovial cavity received in the department during that period were studied. Other fluids were excluded. All the relevant clinical, radiological, biochemical data were obtained. The gross findings were noted, cell count was done in improved Neubaur chamber, then centrifuged at $2000 \mathrm{rpm}$ for $5 \mathrm{~min}$. For hemorrhagic fluids, glacial acetic acid was used as a hemolysing agent and then processed routinely. Cytospin was also used for some samples. Smears were made from the sediment. Both wet fixed and air dried smears were prepared and stained with hematoxylin and eosin, and May Grunwald Giemsa stains respectively. In cases where the cell block was requested, the sediment was fixed in formalin 
and processed like a routine histopathology specimen. Immunohistochemistry (IHC) was done, wherever required, using makers like cytokeratin 7 , cytokeratin 20 , CA 125 , TTF1, etc.

\section{Results}

A total of 302 cases of serous effusions were examined cytologically which included pleural, peritoneal, pericardial and synovial fluids.

Table 1: Age and gender wise distribution of cases

\begin{tabular}{|l|c|c|c|c|c|c|c|c|c|c|c|}
\hline Age & $\begin{array}{c}\text { Pleural } \\
\text { fluid }\end{array}$ & \multicolumn{2}{c|}{$\begin{array}{c}\text { Peritoneal } \\
\text { Fluid }\end{array}$} & \multicolumn{2}{c|}{$\begin{array}{c}\text { Synovial } \\
\text { fluid }\end{array}$} & \multicolumn{2}{c|}{$\begin{array}{c}\text { Pericardial } \\
\text { fluid }\end{array}$} & \multicolumn{2}{c|}{ Total } & $\begin{array}{c}\text { Grand } \\
\text { total }\end{array}$ \\
\hline Sex & M & F & M & F & M & F & M & F & M & F & \\
\hline $0-10$ & 1 & 0 & 0 & 0 & 0 & 0 & 0 & 0 & 1 & 0 & 1 \\
\hline $11-20$ & 6 & 7 & 1 & 2 & 0 & 1 & 0 & 0 & 7 & 10 & 17 \\
\hline $21-30$ & 21 & 10 & 0 & 9 & 1 & 4 & 0 & 1 & 22 & 24 & 46 \\
\hline $31-40$ & 6 & 6 & 4 & 6 & 1 & 2 & 0 & 1 & 11 & 15 & 26 \\
\hline $41-50$ & 19 & 7 & 7 & 32 & 3 & 1 & 3 & 1 & 32 & 41 & 73 \\
\hline $51-60$ & 9 & 8 & 13 & 26 & 2 & 1 & 1 & 1 & 25 & 36 & 61 \\
\hline $61-70$ & 21 & 6 & 3 & 12 & 1 & 3 & 0 & 0 & 25 & 21 & 46 \\
\hline$>70$ & 9 & 12 & 6 & 4 & 1 & 0 & 0 & 0 & 16 & 16 & 32 \\
\hline Total & 92 & 56 & 34 & 91 & 9 & 12 & 4 & 4 & 139 & 163 & 302 \\
\hline $\begin{array}{l}\text { Grand } \\
\text { total }\end{array}$ & \multicolumn{2}{|c|}{148} & \multicolumn{2}{|c|}{125} & \multicolumn{3}{|c|}{21} & \multicolumn{2}{|c|}{8} & 302 & \\
\hline
\end{tabular}

The age ranged from 3 years to 84 years. Female preponderance was observed with M: F ratio of 1:1.17. The most common fluid was pleural, $148(49.0 \%)$ cases, followed by peritoneal fluid, 125 $(41.39 \%)$ cases and least common was pericardial fluid, 8 (2.64\%) cases. The maximum number of cases were seen in the $5^{\text {th }}$ decade.

Table 2: Distribution of effusions on cytological examination

\begin{tabular}{|c|c|c|c|c|c|c|c|}
\hline \multirow{2}{*}{$\begin{array}{l}\text { Type of } \\
\text { fluid }\end{array}$} & \multirow[t]{2}{*}{ Transudate } & \multicolumn{5}{|c|}{ Exudate } & \multirow[t]{2}{*}{ Total } \\
\hline & & 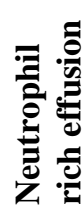 & 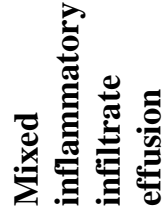 & 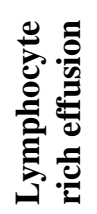 & 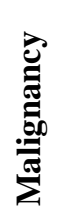 & 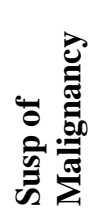 & \\
\hline Pleural & 13 & 7 & 19 & 85 & 21 & 3 & 148 \\
\hline Peritoneal & 50 & 7 & 25 & 9 & 33 & 1 & 125 \\
\hline Synovial & 0 & 14 & 7 & 0 & 0 & 0 & 021 \\
\hline Pericardial & 4 & 0 & 0 & 2 & 2 & 0 & 008 \\
\hline
\end{tabular}

Out of 148 cases of pleural effusion, lymphocyte-rich exudates were most common, 58.62\% followed by malignant effusion $14.18 \%$. Transudates constituted $8.75 \%$.

Out of 125 cases of peritoneal fluids, the maximum numbers of cases were transudates, $40 \%$, followed by malignant effusions, $26.4 \%$.

In synovial fluids analysis $(n=21)$, the maximum cases were of acute suppurative inflammation $66.66 \%$, followed by acute on chronic inflammation, $33.33 \%$.

Out of 8 cases of pericardial effusion, $50 \%$ were transudates, and 2 cases each of malignant effusion and lymphocyte rich effusions were seen. 
Table 3: Malignant effusion

\begin{tabular}{|c|c|c|c|c|c|c|c|c|c|c|}
\hline 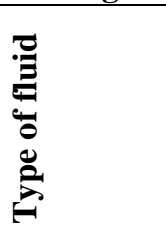 & 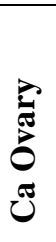 & שَّ & 苞 & 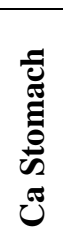 & 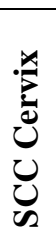 & 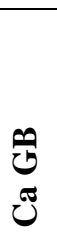 & $\sum_{\sum}$ & 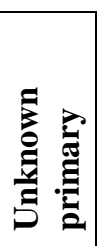 & 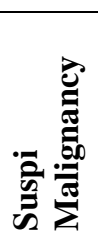 & है \\
\hline Pleural & 3 & 11 & 4 & 0 & 1 & 0 & 0 & 2 & 3 & 24 \\
\hline Peritoneal & 27 & 0 & 0 & 2 & 1 & 1 & 1 & 1 & 1 & 34 \\
\hline Pericardial & 0 & 1 & 1 & 0 & 0 & 0 & 0 & 0 & 0 & 02 \\
\hline Total & 30 & 12 & 5 & 2 & 2 & 1 & 1 & 3 & 4 & 60 \\
\hline
\end{tabular}

$\mathrm{Ca}$ - Adenocarcinoma

SCC - Squamous cell carcinoma

GB - Gall bladder

Suspi - Suspicious

Out of 302 cases of effusions, malignant cells were detected definitely in 56 (18.54\%) cases. Maximum numbers of malignant effusions were peritoneal, $60.71 \%$ followed by pleural $42.85 \%$. Metastatic adenocarcinoma was the commonest malignancy detected in all effusions. The commonest cause of malignant peritoneal and pleural effusions was metastatic adenocarcinoma ovary $(79.41 \%)$ and adenocarcinoma lung $(45.83 \%)$ respectively.

Four cases were suspicious of malignancy. These fluids were slightly hemorrhagic and showed either singly scattered bizarre cells or occasional clusters of atypical cells with high nuclear cytoplasmic ratio. Cell block also revealed the same. Unfortunately there was no follow up.

Table 4: Comparison of our study results with similar studies. $., 7,11$

\begin{tabular}{|c|c|c|c|c|c|c|c|c|c|c|c|c|c|}
\hline \multirow[t]{2}{*}{ Studies } & \multicolumn{3}{|c|}{ Pleural effusions } & \multicolumn{3}{|c|}{$\begin{array}{c}\text { Peritoneal } \\
\text { effusions }\end{array}$} & \multicolumn{3}{|c|}{$\begin{array}{c}\text { Pericardial } \\
\text { effusions }\end{array}$} & \multicolumn{3}{|c|}{$\begin{array}{c}\text { Synovial } \\
\text { effusion }\end{array}$} & Total \\
\hline & 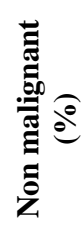 & 营 & 晃 & 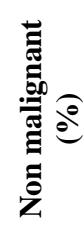 & 栉 & है & 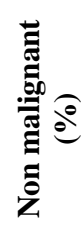 & 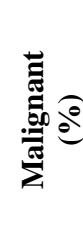 & है & 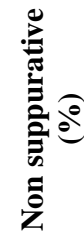 & 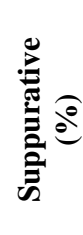 & $\frac{\bar{\sigma}}{6}$ & \\
\hline Shulbha et al & 93.6 & 6.4 & 94 & 97.7 & 2.3 & 174 & \multicolumn{3}{|c|}{ Nil } & 25 & 75 & 8 & 385 \\
\hline $\begin{array}{l}\text { Chakrabarti et } \\
\text { al }\end{array}$ & 91.7 & 8.3 & 400 & 90.5 & 9.5 & 485 & 82.4 & 17.6 & 17 & \multicolumn{3}{|c|}{ Nil } & 902 \\
\hline Kol P.C et al & 77.6 & 22.4 & 76 & 77.7 & 22.3 & 103 & 100 & 0 & 01 & \multicolumn{3}{|c|}{ Nil } & 180 \\
\hline Present study & 83.8 & 16.2 & 148 & 72.8 & 27.2 & 125 & 75 & 25 & 08 & 33.3 & 66.6 & 21 & 302 \\
\hline
\end{tabular}

\section{Discussion}

The cytological examination of effusion fluids in body cavities is a simple procedure and yields vital information of the cell population involving the cavities thereby suggesting the etiology. In cases of malignancies it helps in staging of the malignancy. ${ }^{1-3}$

In our study the most common effusion was pleural, $49.0 \%$, followed by peritoneal effusion $41.39 \%$, which compares well with the study by Kumavat et $\mathrm{al}^{6}$ but is in contrast with the study by Chakrabarti et $\mathrm{al}^{5}$ who found peritoneal effusions more than pleural effusions.

In pleural fluid analysis, maximum numbers of cases were seen in $4^{\text {th }}$ decade followed by $7^{\text {th }}$ decade which is in correlation with Chakrabarti et al study, in which the majority of pleural effusion cases were in the $4^{\text {th }}$ decade. Male preponderance (2.1:1) seen in our study was also observed by the above authors. The effusions with total protein more than $3 \mathrm{gm}$ were taken as exudates. Of all the pleural effusions, lymphocyte rich exudates were the most common effusions, $85(58.62 \%)$ cases followed by malignant effusions $24,(16.21 \%)$ cases. Kumavat et $\mathrm{al}^{6}$ reported similar observation but Chakrabarti et $\mathrm{al}^{5}$ and Shulbha et $\mathrm{al}^{7}$ observed transudates as most common effusions. These lymphocyte rich exudates were clinically suspected as tuberculosis. On cytomorphological examination these effusions revealed cells more than 500 cells/ cu mm with more than $50 \%$ mature lymphocytes and less than $1 \%$ 
mesothelial cells. It correlates well studies by Kushawaha ${ }^{8}$ et al and Tetikkurt et al. ${ }^{9}$ Though we did AFB staining in all cases, none was positive. The second most common pleural effusions were malignant effusions, primary adenocarcinoma lung being the most common etiology. Next in frequency was carcinoma breast followed by carcinoma ovary which is in agreement with Chakrabarti et $\mathrm{al}^{5}$ and other authors. ${ }^{8,9,10}$ We had three cases that were suspicious of malignancy and 2 cases of unknown primary malignancy. Further workup in these cases was not available. Most of the transudates were due to congestive heart failure (CHF), cirrhosis of liver, renal failure or hypoproteinemia. All neutrophil rich effusions (empyema) were due to either pneumonia, post myocardial infarction and the clinical diagnosis was already obvious in such cases. In cases of empyema, the fluid was thick; white to yellowish and contained numerous viable as well as degenerate neutrophils. Similar findings were seen in the study by Kumavat PV et al. ${ }^{6}$

In peritoneal fluid analysis, maximum cases were observed in $6^{\text {th }}$ and $7^{\text {th }}$ decades but Chakrabarti et $\mathrm{al}^{5}$ found maximum cases in $4^{\text {th }}$ decade. Female preponderance was noted (1:2.6) in our study, which is in agreement with above study. Out of the 125 cases of peritoneal fluid, transudates were the predominant effusions, $(40 \%)$, which was similar to many studies. ${ }^{5-7,11}$ Cirrhosis of liver was the commonest etiology. In these cases there were variable infiltrates of lymphocytes, histiocytes and protein was less than $3 \mathrm{gm}$. Next common causes of effusions were malignancies, 33 (26.4\%) cases, with $90 \%$ being due to primary adenocarcinoma of ovary (Fig 1). Kumavat et al, ${ }^{6}$ Chakrabarti et $\mathrm{al}^{5}$ and others reported similar findings. ${ }^{5,6,10,11}$ This may be due to female preponderance and adenocarcinoma ovary is most common malignancy in females. Rest of the malignant peritoneal effusions was due to, squamous cell carcinoma cervix, adenocarcinoma gall bladder (Fig. 2), malignant mixed Mullerian tumor of endometrium and unknown primary, each one case. Jha et al ${ }^{12}$ found adenocarcinoma stomach as most common primary carcinoma affecting peritoneum but we had only two cases of carcinoma stomach affecting the peritoneal fluid.
(A)
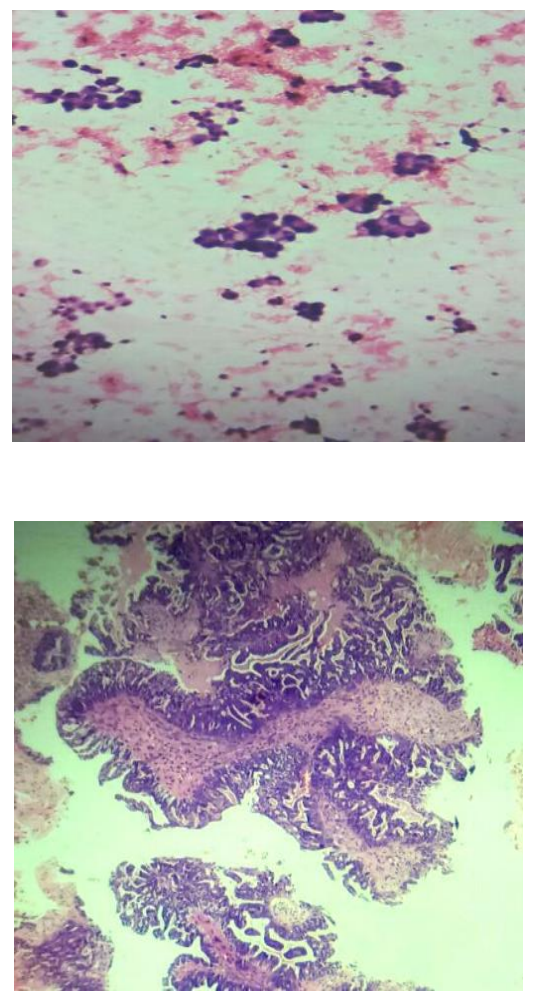

(B)

Fig. 1: Metastatic ovarian papillary serous cystadenocarcinoma. (A): Malignant cells in cohesive clusters and papillae in ascitic fluid (H \& E, 100X); (B): Corresponding histopathology of ovarian carcinoma in the same case shown in $A(H \& E$ 100X)

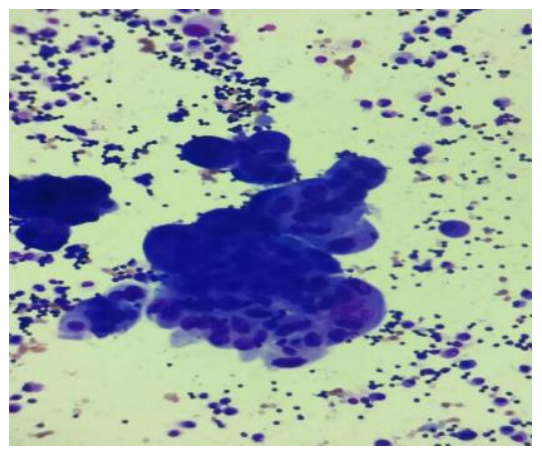

Fig. 2: Smear showing three- dimensional clusters of malignant cells in clinically diagnosed case of carcinoma gall bladder (MGG 100X)

In synovial fluid analysis, maximum cases were seen in $3^{\text {rd }}$ decade and female preponderance was observed. Majority of effusions were suppurative in nature having characteristic turbid, thick, yellowish fluid and were clinically correlated with acute arthritis. Remaining cases were also exudative in nature but revealed mixed inflammatory infiltrate. 
Shulbha et $\mathrm{al}^{7}$ also found suppurative effusions more than non suppurative effusions.

In the present study pericardial fluids were least in number which is comparable to the study by Kol et al. ${ }^{11}$ Out of 8 cases three were in $5^{\text {th }}$ decade and had equal gender distribution. Most, of pericardial effusions, $4(50 \%)$ cases were transudative in nature and they were clinically suspected cases of pericarditis, post myocardial infarction which is similar to Chakrabarti et al study. In remaining half cases, two were of lymphocyte rich effusion and other two were of malignant effusion, one case each of primary breast and lung adenocarcinoma. Chakrabarti et $\mathrm{al}^{5}$ and Robert et $\mathrm{al}^{13}$ also observed that the most common cause of malignant pericardial effusion was adenocarcinoma breast.

In the present study, 44 out of 60 cases with malignant effusion already had a known primary malignancy. Remaining cases, presented with effusion only, where cytology picked up malignancy. Of these, cell block, IHC study and correlation with radiology identified the primary malignancy in eleven cases, and three $(5 \%)$ remained as unknown primary. Fig. 3 demonstrates immunoreactivity for CA 125 in Cell block of ascitic fluid indicating the possibility of carcinoma ovary. Cases of suspicious of malignancy were lost to follow up. Shulbha et al and Luse et al in their study found $40 \%$, and $15 \%$ respectively, as overall rate of unknown primary. In addition to cytomorphology, immunocytochemistry, clinical correlation and follow up help in detecting the primary malignancy. ${ }^{15,16}$

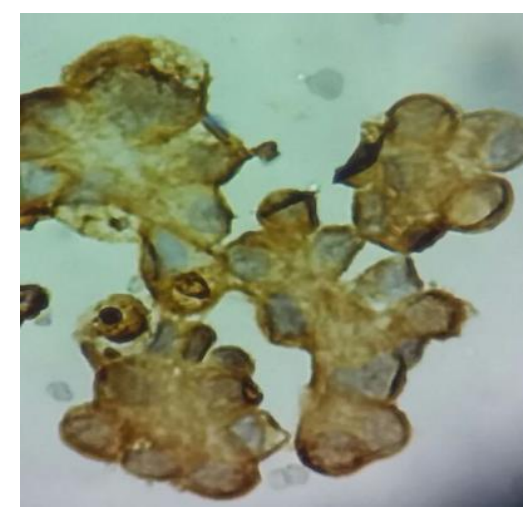

Fig. 3: Immunoreactivity of tumor cells for CA 125 on cell block preparation (400X)

In some inflammatory effusions, we encountered difficulties in identifying reactive mesothelial cells and distinguishing them from malignant cells. However, the morphologic changes in these cells were not sufficient enough to be concluded as malignant. We applied a "two cell population" approach in identifying metastatic tumor cells in addition to cytomorphology and ancillary studies such as immunocytochemistry wherever necessary. Reactive mesothelial cells are identified by the presence of two zones in cytoplasm, cohesive clusters with scalloped (knobby) contours, cellin- cell configuration and mesothelial windows. ${ }^{2,17,18}$

\section{Conclusions}

We conclude in our study that cytology is a valuable tool in evaluation of serous cavity fluids. It is relatively painless, simple, cost effective, rapid technique that yields quick and reliable results. Some cases may present major interpretative challenges to the pathologist. Ancillary studies such as cell count, biochemical, microbiologic evaluation, cell block and IHC study help in accurate identification of diagnosis. It is especially helpful in evaluating and staging malignancies thereby guiding the clinician in further management.

In our study, pleural fluid was the commonest type of serous fluid in which the majority of cases were lymphocyte-rich effusions favouring tuberculosis. Adenocarcinoma was the most common malignancy involving serous cavities. In transudates, the diagnosis helped the clinician in evaluating the causes and in follow up of the cases.

\section{References}

1. Koss LG, Melamed MR. Effusions in the absence of cancer. In : Koss LG, editor. Koss' Diagnostic Cytology and Its Histopathologic Bases. Vol 2, $5^{\text {th }}$ ed. Philadelphia, Lippincott Williams \& Wilkins;2006.p.919-46.

2. Shidham VB, Falzon M. Serous effusions. In: Gray W, Kocjan G: editors. Diagnostic Cytopathology, 3rd Edition. Churchill Livingstone, Elsevier 2010;115-75.

3. Frist B, Kahan AV, Koss LG. Comparison of the diagnostic values of biopsies of pleura and cytological evaluation of pleural fluids. Am J Clin Pathol 1979;72:48-5.

4. Sherwani R, Akhtar K, Naqvi AH, Akhtar S, Abrari A, Bhargava R. Diagnostic and prognostic significance of cytology in effusions. J cytol 2005;22:73-7.

5. Chakrabarti PR, Kiyawat P, Varma A, Agrawal P, Dosi S, Dixit M. Cytological evaluation of serous body fluids: A two year experience in tertiary care centre from Central India Int J Cur Res Rev 2015;7(17):1-4.

6. Kumavat PV, Kulkarni MP, Sulhyan KR. Cytological study of Effusions. Indian Medical Gazette. 2013;August:306-13.

7. Shulbha VS, Dayananda BS. Cytology of body fluids - An aid to primary diagnosis. Indian 
Journal of Pathology and Oncology 2015;2(2):81-

3.

8. Kushwaha R, Shashikala P, Hiremath S,

Basavsraj HG. Cells in pleural fluid and their value in differential diagnosis. $\mathrm{J}$ Cytol 2008;25:138-43.

9. Tetikkurt C, Kara BY, Tetikkurt S, Yilmaz N, Yasar I, Disci R. The value of cytology in the diagnosis of pleural effusions. British journal of medicine and medical research 2014;4(1):220311.

10. Gupta S, Sodhani P, Jain S. Cytomorphological profile of neoplastic effusions: An audit of 10 years with emphasis on uncommonly encountered malignancies. J Can Res Ther 2012;8:602-9.

11. Kol PC, Singh SK, Singh UR .Diagnostic value of exfolative cytology in evaluation of serous effusions. International journal of scientific research 2016;5(2):244-6.

12. 12.Jha R, Shrestha HG, Sayami G, Pradhan SB. Study of effusion cytology in patients with simultaneous malignancy and ascitis. Kathmandu University Medical Journal 2006;4:483-7.

13. Zipf RE, Johnston WW. The role of cytology in the evaluation of Pericardial effusions. Chest 1972;62:593-6.

14. Luse SA, Reagen JW. Histologic and electron microscopic study of effusions associated with malignant disease. Ann MY Acad Sci 1956;63:1331-47.

15. Kaur G, Nijhawan R, Gupta N, Singh N, Rajwanshi A. Pleural fluid cytology samples in cases of suspected lung cancer: An experience from a tertiary care centre. Diagn Cytopathol. 2017 Mar;45(3):195-201.

16. Dixit R, Agarwal KC, Gokhroo A, Patil CB, Meena M, Shah NS, et al. Diagnosis and management options in malignant pleural effusions. Lung India 2017;34:160-6.

17. Anita B, Ahuja JM. Evaluation of Coelomic Fluids and its Clinical Correlation with Cytologic Diagnosis. J Cytol Histol 2016;7(2):397.

18. Lin O. Challenges in the Interpretation of Peritoneal Cytologic Specimens. Arch Pathol Lab Med 2009;133:739-42. 